\title{
Present and future perspectives of using biological control agents against pests of honey bees
}

\author{
Hossam F. Abou-Shaara ${ }^{1 *}$ and Martin Staron ${ }^{2}$
}

\begin{abstract}
Honey bee, Apis mellifera L., is considered as an essential organism to the agricultural sector due to its role in pollination and alleviation of poverty in rural areas. Many pests attack honey bee colonies causing severe damages and economic losses. These pests include Varroa mites, Vespa hornets, wax moths, small hive beetles, and parasitic flies. Using chemical methods to control these pests causes some negative effects on honey bees and contaminates their products, while using biological control agents is promising and has no serious hazards. This article aimed to review available studies on the role of biological control agents mainly predators, parasitoids, and pathogens in controlling bee's pests and to present new perspectives. Also, obstacles of using biocontrol agents inside and outside the hives were presented. This article is essential for planning integrated management programs for honey bee pests.
\end{abstract}

Keywords: Honey bee, Apis mellifera, Biological control, New perspectives, Review

\section{Background}

Honey bee, Apis mellifera L., occurs worldwide, and it is the main pollinator of many plants (Corbet et al. 1991 and Morse and Calderone 2000). Beekeeping is among the most important agricultural activities thanks to its role in providing many job opportunities at rural areas besides the valuable products of honey bees. These products include, honey, pollen, royal jelly, bee venom, beeswax, and propolis, and have many medicinal uses (e.g., De Castro 2001; Nagai and Inoue 2004 and Eteraf-Oskouei and Najafi 2013). Recently, the loss of honey bee colonies has been recorded in different parts of the world, a phenomenon called colony collapse disorder (CCD) (Maini et al. 2010). The specific reasons behind the CCD are not fully known, but it mostly happens due to a number of harmful factors (van Engelsdorp et al. 2009 and Neumann and Carreck 2010). Unfortunately, many pests such as Varroa mites, wax moths, small hive beetles, Vespa hornets, and parasitic flies attack honey bee colonies causing serious damages (Core et al. 2012; Dietemann et al. 2013; Ellis et al. 2013;

\footnotetext{
* Correspondence: hossam.farag@agr.dmu.edu.eg

'Department of Plant Protection, Faculty of Agriculture, Damanhour

University, Damanhour 22516, Egypt

Full list of author information is available at the end of the article
}

Monceau et al. 2014; and Neumann et al. 2016). The use of chemicals to control these pests is not recommended. For example, acaricides and other chemicals that used to control Varroa mites can contaminate bee products (Bogdanov 2006) and can impact negatively the health of honey bees (Abou-Shaara et al. 2017a). On the other side, the Varroa mites can develop resistance to them (Pettis 2004). Also, organic beekeeping practices do not accept the application of chemicals (Lodesani et al. 2008 and Iancu et al. 2012). Searching for safe and sustainable alternatives to control honey bee pests is a very important approach. Also, the use of biological control agents; predators, parasitoids, or pathogens to control the pests can be considered as suitable choices. Biocontrol agents are expected to manage the population of bee pests without causing harmful effects on honey bees and without contaminating valuable bee products.

This report aimed to review the available studies on using biocontrol agents, especially predators, parasitoids, and pathogens to control pests of honey bees and to suggest future perspectives. Additionally, the gaps in knowledge and points require detailed investigations are highlighted. 


\section{Mites}

There are various mites that can attack honey bees, especially Varroa mites, Varroa destructor Anderson and Trueman (Acari: Varroidae) (Dietemann et al. 2013), and Tropilaelaps mites (Anderson and Roberts 2013), but Varroa mites are more common than Tropilaelaps. These mites feed on the hemolymph of bees, leading to the loss of heavily infested colonies. Also, Varroa mites can host many pathogens, including viruses (Chen et al. 2004) and harmful bacteria (Burritt et al. 2016). The control of Tropilaelaps is easy because these mites infect only immature stages, while the Varroa mites infect both immature and mature stages (Dietemann et al. 2013). Available methods to control Varroa mites include acids, essential oils, acaricides, or mechanical methods, but the efficiency of these methods are not constant or even high and the Varroa can escape them, therefore continues management strategy was suggested (Abou-Shaara 2014). Few biological control agents have been suggested to be used against the Varroa mites (Chandler et al. 2001). Only entomopathogenic fungi and Chelifers (pseudoscorpions) have gained attention and have shown some efficacy in some studies as shown in the next paragraphs.

\section{Biocontrol agents \\ Pathogens}

The entomopathogenic fungus Metarhizium anisopliae showed efficacy against Varroa mites under laboratory (Kanga et al. 2002; Shaw et al. 2002; García-Fernández et al. 2008) and field conditions (Gerritsen and Cornelissen 2006; Kanga et al. 2006; Rodríguez et al. 2009; Hamiduzzaman et al. 2012 and Ahmed and Abd-Elhady 2013). On the contrary, field experiments using $M$. anisopliae against Varroa mites showed negative impact (Gerritsen and Cornelissen 2006 and James et al. 2006). In fact, studies that support the efficacy of $M$. anisopliae are more than those do not. The reported efficacy ranged 85-100\% (Kanga et al. 2002 and Rodríguez et al. 2009). Most of the studies confirmed the efficacy of $M$. anisopliae within 7-8 days post-treatment (Kanga et al. 2003 and Meikle et al. 2006), without negative impacts on immature (Ahmed and Abd-Elhady 2013) and mature stages of honey bees (Kanga et al. 2002; Kanga et al. 2003; Ahmed and Abd-Elhady 2013), and queens (Kanga et al. 2002). The direct contact between Varroa mites and fungi happened under laboratory conditions but under field conditions various applications methods were used including dusting (Kanga et al. 2003), strips coated with the fungal conidia (Kanga et al. 2006), and placing inoculated mites with spore solutions in beehives (Hamiduzzaman et al. 2012). The appropriate period for application was the period when no or low brood is present in the colonies (Kanga et al. 2006).
The second major entomopathogenic fungi, Beauveria bassiana, showed also efficacy against Varroa mites under laboratory (Shaw et al. 2002) and field conditions (Meikle et al. 2008; Hamiduzzaman et al. 2012; Ahmed and Abd-Elhady 2013 and Sewify et al. 2015). These fungi were also isolated from Varroa mites in capped worker brood cells (Steenberg et al. 2010). The death of Varroa infected with fungi usually happened between 5 to 10 days (Meikle et al. 2007). Fortunately, treatments showed no negative impacts on colony health (Meikle et al. 2008), or immature and mature stages of bees (Ahmed and Abd-Elhady 2013). Meikle et al. (2012) recorded high death rates of bees and mites in colonies treated with a commercial biopesticide contained conidia of a strain of B. bassiana isolated from Varroa.

Some other entomopathogenic fungi were also tested in few studies and showed efficacy such as Clonostachys rosea under field conditions (Hamiduzzaman et al. 2012), Hirsutella thompsonii under laboratory conditions (Peng et al. 2002) and field conditions (Kanga et al. 2002) without impacting honey bees, while Lecanicillium lecanii showed no efficacy against Varroa (Gerritsen and Cornelissen 2006). The efficacy of $M$. anisopliae and $B$. bassiana against Varroa, supported by previous studies, has shown that application methods and suitable periods for applications still need further studies, especially under various environmental conditions. Also, the pathogenicity of other fungi against Varroa mites needs additional investigations.

\section{Predators}

In Europe, Chelifer cancroides is an interesting predatory species for beekeeping. It was firstly observed inside bee colonies in 1891 by Alois Alfonsus (Schiffer 2017). Christophoryová et al. (2012) created a checklist of the pseudoscorpions with 38 species from the Czech Republic and 51 species from Slovakia, formerly Czechoslovakia. In south India, pseudoscorpion Ellingsenius indicus was observed inside bee colonies (Subbiah et al. 1957). Also, pseudoscorpions were observed in New Zealand (Fagan et al. 2012), Cameroon (Fombong et al. 2016), and in some Arabian countries including Egypt (personal observations). Fagan et al. (2012) reported that 25 pseudoscorpions were sufficient to manage the population of Varroa within hives. Mass-rearing methods for two pseudoscorpions (Nesochernes gracilis and Heterochernes novaezealandiae) were developed in New Zealand, and N. gracilis showed the most promising role for biological control of Varroa (Read et al. 2014). Also, a molecular technique based on detection of Varroa DNA in extractions of pseudoscorpion DNA was developed to confirm the predation in commercial hives without the need for observation (van Toor et al. 2015). Rangel and Ward (2018) evaluated the ability of the predatory mite Stratiolaelaps scimitus 
(Mesostigmata: Laelapidae) to control Varroa under laboratory and field conditions. In vials, $97.10 \%$ of the exposed Varroa to the predatory mites died after $24 \mathrm{~h}$, while only $6.85 \%$ died in the control group. Under field conditions, S. scimitus showed insignificant impact on Varroa. This study gave some hope to utilize $S$. scimitus as a potential biological control agent to Varroa. In fact, few studies have been conducted on the predators of Varroa, especially under hive conditions. It seems that using entomopathogenic fungi is more effective and practical than predators.

\section{Wax moths}

There are two species of wax moths, the greater wax moths (GWM), Galleria mellonella L., and the lesser wax moths (LWM), Achoria grisella F. (Lepidoptera: Pyralididae). These moths attack wax combs to feed on cast larval skins and stored food. They can destroy wax combs either inside or outside the hives (Ellis et al. 2013; Kwadha et al. 2017). Wax moths invade weak colonies; hence, such colonies can be completely destroyed by their larvae. There are different mechanical and chemical methods to control wax moths, outside the hives (Ellis et al. 2013), but inside the hives, the control options are very limited and mainly depend on boosting the strength of colonies, or using specific traps (Abou-Shaara 2017a). The biology of these moths has been well studied, and they can complete their development on different types of food (Coskun et al. 2006) and on paper wasp nests (Abou-Shaara 2017b). These wax moths are used in some beneficial aspects like mass rearing of the egg parasitoid Trichogramma species (Boldt and Marston 1974) and to get rid of plastic wastes (Bombelli et al. 2017).

\section{Biocontrol agents Pathogens}

There are a few studies on using microbial agents to control the wax moths. The common microbial agent, is the entomopathogenic bacteria, Bacillus thuringiensis (Bt) (Burges 1978) that applies on empty combs. Bt produces a variety of stomach toxins to larvae. Presently, there are some commercial formulations of $B t$ available for controlling wax moths in stored combs. But the efficacy of $B t$ is not persistence (Kwadha et al. 2017). Benzina et al. (2017) isolated 9 Bacillus strains from GWM larvae, and the strain S4 caused a mortality rate of (5083.3\%) to GWM after 3 days. Hanley et al. (2003) studied the possibility of using transgenic $B t$ corn pollen to control wax moth larvae without negative impacts on honey bees in laboratory trials. More studies are still required to assess the efficacy of $B t$ against GWM and LWM larvae under store and hive conditions considering any negative impacts on honey bees. Other pathogens like alimentary tract parasites, neoaplectanid nematode DD-136, to GWM (Poinar Jr and Himsworth 1967) and entomopathogenic fungi (Serebrov et al. 2006) were studied in regard to their impacts on physiology of wax moths and were not utilized as biological control agents.

\section{Parasitoids}

The parasitoids, especially Bracon hebetor (Say.) and Apanteles galleriae (Wilkinson) (Hymenoptera: Braconidae), are potential biocontrol agents to wax moths (Kwadha et al. 2017). A. galleriae causes disturbance in development and alterations in the endocrine system of GWM larvae (Wanl et al. 1994), while the venom of $B$. hebetor showed negative effects on GWM reducing oxygen consumption of larvae (Waller 1965), meanwhile GWM can be used for mass rearing of B. hebetor (Alam et al. 2015). In fact, these two parasitoids attack wax moth larvae in stored combs outside hives or inside empty hives. Personal observations confirm the ability of these parasitoids to attack wax moths only on combs without adult bees and not inside the crowded hives. It seems that the parasitoids cannot be used under hive conditions because bees prevent them from access to inside hives. Also, wax moth larvae usually occur within wax combs and cannot be easily detected by the parasitoids inside crowded hives. Thus, $B t$ and parasitoids are suitable under store conditions, while only $B t$ can be used under hive conditions.

\section{Small hive beetles}

The small hives beetle (SHB) Aethina tumida Murray (Coleoptera: Nitidulidae) was recorded in some countries including the UK, USA, Italy, Sudan, and Korea (El-Niweiri et al. 2008; Palmeri et al. 2015 and Neumann et al. 2016), but not in Egypt (Hassan and Neumann 2008 and Abou-Shaara et al. 2018). SHB invades honey bee colonies and its larvae feed on stored food and wax causing damages to combs. The larvae pupate in the soil (Frake and Tubbs 2009). Various methods are available to control the pest such as baits (Arbogast et al. 2007) and irradiation (Downey et al. 2015).

\section{Biocontrol agents}

Entomopathogenic fungi (Muerrle et al. 2006) and entomopathogenic nematodes (Ellis et al. 2010) are major biological control agents found attacking the SHB (Cuthbertson et al. 2012). Besides, there are some minor agents including Aspergillus niger and A. flavus (Richards et al. 2005), the storage mite Caloglyphus hughesi (Strauss et al. 2010), the ant Pheidole megacephala, as a predator of larvae (Torto et al. 2010), and a protozoan pathogen (Wright and Steinkraus 2013) have been reported. Mortality of SHB increased when $B$. bassiana and M. anisopliae variety anisopliae were used, 
using spore suspension bioassays. Hirsutella illustris and M. anisopliae showed no impact (Muerrle et al. 2006). SHB larvae were susceptible to entomopathogenic nematodes Heterorhabditis megidis, Steinernema carpocapsae, and S. riobrave with (95\%) fiducial limits of 120-231, 124-262, and 150-504, and $\mathrm{LC}_{50}$ of 157, 164, and 204 infective juveniles/insect larvae, respectively (Cabanillas and Elzen 2006). In another study, the two nematode species; S. riobrave and Heterorhabditis indica showed potential to control SHB for 19 weeks with 7694\% mortality after a single soil inoculation and 88 to $100 \%$ mortality rate in the field bioassay (Ellis et al. 2010). Also, H. indica showed efficacy against SHB, using the tape-formulation approach under laboratory conditions (Shapiro-Ilan et al. 2010). Moreover, high virulance was found by Steinernema kraussei and S. carpocapsae to control SHB causing 100\% mortality of larvae, and the efficacy extended for 3 weeks in soil (Cuthbertson et al. 2012). Entomopathogenic fungi and nematodes are promising bioagents to control SHB but more studies are required, especially under field conditions considering different soil types. Also, the appropriate application methods of these biological agents need to be determined to ensure the sustainability of these agents.

\section{Hornets}

Different species of Vespa hornets (Hymenoptera: Vespidae) attack honey bees and may invade the colonies and destroy them. These hornets feed on immature and mature bees, virgin and mated queens, and stored food inside the colonies. The species belong to genus Vespa that occur at various countries (Archer 1998). Typically, Vespa orientalis Linnaeus, 1771 attacks honey bees at the Middle East, North Africa, and South Europe, while other species occur in Asian countries. The Asian hornets, Vespa velutina Lepeletier, 1836 has been recently considered as an invasive pest to Europe (Monceau et al. 2014 and Turchi and Derijard 2018). Traps with different type of baits are used to manage the hornets (but the efficiency of these traps is impacted by various factors and is not sustainable (Demichelis et al. 2014).

\section{Biocontrol agents Pathogens}

There are various pathogens to Vespa hornets but they are temporarily used to infect hornet nests (Rose et al. 1999). To a certain extent, the nematodes (Pheromermis spp.) were predicted to have negative impacts on the social wasps (Vespinae) and produced sexuals (Martin 2004). Their use may be helpful to manage the nests of harmful hornets. Few parasitic nematodes mermithids (Pheromermis spp.) were recorded in France without expectation of being suitable as biological control agents
(Villemant et al. 2015). Entomopathogenic fungi, isolated from France and applied as direct inoculation method, walking on a contaminated surface, in the food, or by inter-individual transfers showed efficacy against $V$. velutina (Poidatz et al. 2018). Generally, utilizing pathogens to control Vespa has not been supported by previous studies, and this may be explained by the social nature of Vespa hornets. However, isolating of pathogens from nests and developing application methods are still required to manage hornets beside other control means.

\section{Parasitoids}

The parasitoid species, Sphecophaga vesparum Curtis (Hymenoptera: Ichneumonidae), was found attacking up to $100 \%$ of $V$. orientalis nests, causing a reduction in production of queen cells (Donovan 1991 and Havron and Margalith 1995). It was recorded in northern Jordan as a natural enemy of Vespa orientalis (Haddad et al. 2005). In New Zealand, Beggs et al. (2008) recorded 17\% parasitization with $S$. vesparum vesparum, and the high parasitoid density showed no noticeable effect on the host nest, suggesting less suitability as biological control agent. As well, the indigenous parasitoids, Conopid flies in France, showed no suitability to serve as biological control agent (Villemant et al. 2015). The parasitoid, Sphecophaga can be considered as a promising parasitoid to control hornets. Additional investigations to develop the methods of its mass rearing and to enhance its efficacy are needed.

\section{Parasitic fly}

One of the new threats to honey bees is the parasitic fly, Apocephalus borealis Brues (Diptera: Phoridae), which recorded in some countries including the USA (Core et al. 2012), and Saudi Arabia (Mohammed 2018). This fly attacks the bees outside hives, and its parasitic larvae destroy the body of infected bees. The infected bees have some abnormal movements and crawl on the ground (Core et al. 2012). The fly control options are very limited and need intensive research studies. Also, the fly species Megaselia rufipes and M. scalaris (Diptera: Phoridae) were recorded as facultative parasitoids to honey bees in Italy (Ricchiuti et al. 2016). M. scalaris was recorded also in Cameroon (Cham et al. 2018). The biocontrol agents of these parasitic flies are not yet available.

\section{Obstacles of using biocontrol agents}

Temperature at brood nest ranges from 33 to $36^{\circ} \mathrm{C}$ and is actively regulated by bees utilizing different methods (Abou-Shaara et al. 2017b). This temperature range represents a challenge to the role of biocontrol agents that can be used inside the hives to control Varroa mites, wax moths, or small hive beetles. Therefore, screening 
the survival ability of the selected biocontrol agents to hive microclimate is a necessary step to determine the appropriate control agents. For example, temperature is very important factor for the efficacy of entomopathogenic fungi (Davidson et al. 2003), but few isolates of $M$. anisopliae and B. bassiana could tolerate the $35^{\circ} \mathrm{C}$ (Rodríguez et al. 2009).

Another problem is the behavior of honey bees against used agents inside the hives, especially parasitoids and predators, as the honey bees may attack these agents and suppress their efficacy. On the other side, the used agents inside hives may infect honey bees or cause passive impacts on colony performance, especially egg laying by queens or brood rearing. Therefore, field trails are very essential to assess the reactions of bees against utilized agents and to ensure the absence of any negative impacts on immature and mature stages of bees. Additionally, the overlapping between beekeeping practices including regular inspections of hives, artificial feeding, transportation of hives, or using chemicals inside hives and biocontrol agents should be taken into account and properly and regularly evaluated.

Ecological factors, especially the air temperature, life cycle of the target pests, and timing of using microbial agents or parasitoids should be considered during the applications of biocontrol agents to ensure the efficacy of the agents. Moreover, environmental contamination with pesticides or other pollutants should not be neglected because such pollutants can negatively impact the efficacy of the used agents. Additionally, the indirect impacts of used biocontrol agents against non-target organisms other than bees should be taken into consideration.

\section{Conclusion and future perspectives}

Predators, parasitoids, and/or microbial biopesticides are available to pests of honey bees, except the parasitic flies. In general, these biocontrol agents cannot be used alone to control the pests of honey bees, but they should be implemented in well planned integrated pest management programs. Searching for more specific and effective biocontrol agents is very essential, especially under future climate change challenges, which can greatly impact honey bees (Le Conte and Navajas 2008). Geographical information system (GIS) has been recently used in beekeeping for many purposes (e.g., Estoque and Murayama 2010 and Abou-Shaara et al. 2013). This system can be also used to map and evaluate the efficacy of biocontrol agents applied outside hives. The geographical locations of suitable local predators or parasitoids can be mapped and analyzed, using GIS to better understand the habitat of these agents and hence suitable environmental conditions for utilizing these agents can be identified. Implementing GIS with biological control strategies can be considered as a good perspective to detect new biocontrol agents and to evaluate their efficacy. Also, searching for suitable and cost-effective methods to rear parasitoids and predators of honey bee pests is very essential and should be continually developed. Moreover, the application methods of microbial biopesticides need more development to ensure the sustainable release of these microbes and hence long term efficacy.

\section{Abbreviations \\ Bt: Bacillus thuringiensis; CCD: Colony collapse disorder; GIS: Geographical information system; GWM: Greater wax moth; LWM: Lesser wax moth; \\ SHBs: Small hive beetles; SIT: Sterile insect technique}

\section{Acknowledgements}

Not applicable.

Funding

Not applicable.

Availability of data and materials

All references that support the study are included in the manuscript.

Authors' contributions

HA-S designed the study. HA-S and MS wrote and revised the manuscript. All authors read and approved the final manuscript.

Ethics approval and consent to participate

Not applicable.

Consent for publication

Not applicable.

Competing interests

The authors declare that they have no competing interests.

\section{Publisher's Note}

Springer Nature remains neutral with regard to jurisdictional claims in published maps and institutional affiliations.

\section{Author details}

${ }^{1}$ Department of Plant Protection, Faculty of Agriculture, Damanhour University, Damanhour 22516, Egypt. ${ }^{2}$ Research Institute for Animal Production Nitra, Institute of Apiculture, Liptovský Hrádok, Slovakia.

Received: 14 January 2019 Accepted: 21 March 2019

Published online: 11 April 2019

\section{References}

Abou-Shaara HF (2014) Continuous management of Varroa mite in honey bee, Apis mellifera, colonies. Acarina 22:149-156

Abou-Shaara HF (2017a) Evaluation of non-chemical traps for management of wax moth populations within honey bee colonies. J Agr Urban Entomol 33: $1-9$

Abou-Shaara HF (2017b) Greater wax moth larvae can complete development on paper wasp nest. J Agr Urban Entomol 33:57-60

Abou-Shaara HF, Ahmad ME, Háva J (2018) Note: recording of some beetles in honey bee colonies. Agronom Res Mold 51:85-90

Abou-Shaara HF, Al-Ghamdi AA, Mohamed AA (2013) A suitability map for keeping honey bees under harsh environmental conditions using geographical information system. World Appl Sci J 22:1099-1105

Abou-Shaara HF, Owayss AA, Ibrahim YY, Basuny NK (2017b) A review of impacts of temperature and relative humidity on various activities of honey bees. Insect Soc 64:455-463

Abou-Shaara HF, Staron M, Cermáková T (2017a) Impacts of oxalic acid, thymol, and potassium citrate as Varroa control materials on some parameters of honey bees. Turk J Vet Anim Sci 41:238-247 
Ahmed AA, Abd-Elhady HK (2013) Efficacy of two fungus-based biopesticide against the honeybee ectoparasitic mite, Varroa destructor. Pak J Biol Sci 16: 819-825

Alam M, Alam S, Miah M, Mian M, Hossain M (2015) Mass rearing of Bracon hebetor (Hym.: Braconidae) on wax moth, Galleria mellonella (Lep.: Pyralidae) with varying density of parasitoid and the host. J Crop Prot 5:39-48

Anderson DL, Roberts JM (2013) Standard methods for Tropilaelaps mites research. J Apic Res 52:1-16

Arbogast RT, Torto B, Van Engelsdorp D, Teal PE (2007) An effective trap and bait combination for monitoring the small hive beetle, Aethina tumida (Coleoptera: Nitidulidae). Flo Entomol 90:404-406

Archer ME (1998) Taxonomy, distribution and nesting biology of Vespa orientalis L. (Hym., Vespidae). Entomol Mon Mag 134:45-51

Beggs JR, Rees JS, Toft RJ, Dennis TE, Barlow ND (2008) Evaluating the impact of a biological control parasitoid on invasive Vespula wasps in a natural forest ecosystem. Biol Control 44:399-407

Benzina F, Oulebsir-Mohandkaci H, Belaid M, Irnatene H, Mammeri S (2017) Isolation of entomopathogenic bacteria from larvae of a lepidopteran specie; Galleria mellonella and study of their insecticidal effect. Agri For 63:59-68

Bogdanov S (2006) Contaminants of bee products. Apidologie 37:1-18

Boldt PT, Marston N (1974) Eggs of the greater wax moth as a host for Trichogramma. Environm Entomol 3:545-548

Bombelli P, Howe CJ, Bertocchini F (2017) Polyethylene bio-degradation by caterpillars of the wax moth Galleria mellonella. Curr Biol 27:R292-R293

Burges HD (1978) Control of wax moths: physical, chemical and biological methods. Bee world 59:129-138

Burritt NL, Foss NJ, Neeno-Eckwall EC, Church JO, Hilger AM, Hildebrand JA, Warshauer DM, Perna NT, Burritt JB (2016) Sepsis and hemocyte loss in honey bees (Apis mellifera) infected with Serratia marcescens strain sicaria. PLoS One 11:e0167752

Cabanillas HE, Elzen PJ (2006) Infectivity of entomopathogenic nematodes (Steinernematidae and Heterorhabditidae) against the small hive beetle Aethina tumida (Coleoptera: Nitidulidae). J Apic Res 45:49-50

Cham DT, Fombong AT, Ndegwa PN, Irungu LW, Nguku E, Raina SK (2018) Megaselia scalaris (Diptera: Phoridae), an opportunist parasitoid of honey bees in Cameroon. Afr Entomol 26:254-258

Chandler D, Sunderland KD, Ball BV, Davidson G (2001) Prospective biological control agents of Varroa destructor n. sp., an important pest of the European honeybee, Apis mellifera. Biocontrol Sci Tech 11:429-448

Chen Y, Pettis JS, Evans JD, Kramer M, Feldlaufer MF (2004) Transmission of Kashmir bee virus by the ectoparasitic mite Varroa destructor. Apidologie 35:441-448

Christophoryová J, Stahlavsky F, Krumpál M, Fedor P (2012) Pseudoscorpions of the Czech Republic and Slovakia: an annotated and revised checklist (Arachnida: Pseudoscorpiones). Nor-West J Zool 8:1-21

Corbet SA, Williams $H$, Osborne $J$ (1991) Bees and the pollination of crops and wild flowers in the European Community. Bee world 72:47-59

Core A, Runckel C, Ivers J, Quock C, Siapno T, DeNault S, Brown B, DeRisi J, Smith CD, Hafernik J (2012) A new threat to honey bees, the parasitic phorid fly Apocephalus borealis. PLoS One 7:e29639

Coskun M, Kayis T, Sulanc M, Ozalp P (2006) Effects of different honeycomb and sucrose levels on the development of greater wax moth Galleria mellonella larvae. Inter J Agri Biol 8:855-858

Cuthbertson AGS, Mathers JJ, Blackburn LF, Powell ME, Marris G, Pietravalle S, Brown MA, Budge GE (2012) Screening commercially available entomopathogenic biocontrol agents for the control of Aethina tumida (Coleoptera: Nitidulidae) in the UK. Insects 3:719726

Davidson G, Phelps K, Sunderland KD, Pell JK, Ball BV, Shaw KE, Chandler D (2003) Study of temperature-growth interactions of entomopathogenic fungi with potential for control of Varroa destructor (Acari: Mesostigmata) using a nonlinear model of poikilotherm development. J Appl Microbiol 94:816-825

De Castro SL (2001) Propolis: biological and pharmacological activities. Therapeutic uses of this bee-product. Annu Rev Biomed Sci 3:49-83

Demichelis S, Manino A, Minuto G, Mariotti M, Porporato M (2014) Social wasp trapping in north West Italy: comparison of different bait-traps and first detection of Vespa velutina. Bull Insectol 67:307-317

Dietemann V, Nazzi F, Martin SJ, Anderson DL, Locke B, Delaplane KS, Wauquiez Q, Tannahill C, Frey E, Ziegelmann B, Rosenkranz P (2013) Standard methods for Varroa research. J Apic Res 52:1-54

Donovan BJ (1991) Life cycle of Sphecophaga vesparum (Curtis)(Hymenoptera: Ichneumonidae), a parasitoid of some vespid wasps. New Zealand J Zool 18: 181-192
Downey D, Chun S, Follett P (2015) Radiobiology of small hive beetle (Coleoptera: Nitidulidae) and prospects for management using sterile insect releases. J Econ Entomol 108:868-872

Ellis JD, Graham JR, Mortensen A (2013) Standard methods for wax moth research. J Apic Res 52:1-17

Ellis JD, Spiewok S, Delaplane KS, Buchholz S, Neumann P, Tedders WL (2010) Susceptibility of Aethina tumida (Coleoptera: Nitidulidae) larvae and pupae to entomopathogenic nematodes. J Econ Entomol 103:1-9

El-Niweiri MA, El-Sarrag MS, Neumann P (2008) Filling the Sudan gap: the northernmost natural distribution limit of small hive beetles. J Apic Res 47: 184-185

Estoque RC, Murayama Y (2010) Suitability analysis for beekeeping sites in La Union, Philippines, using GIS and multi-criteria evaluation techniques. Res J Appl Sci 5:242-253

Eteraf-Oskouei T, Najafi M (2013) Traditional and modern uses of natural honey in human diseases: a review. Iran J Basic Med Sci 16:731

Fagan LL, Nelson WR, Meenken ED, Howlett BG, Walker MK, Donovan BJ (2012) Varroa management in small bites. J Appl Entomol 136:473-475

Fombong AT, Cham DT, Nkoba K, Neethling JA, Raina SK (2016) Occurrence of the pseudoscorpions Ellingsenius ugandanus and Paratemnoides pallidus in honey bee colonies in Cameroon. J Apic Res 55:247-250

Frake AM, Tubbs H (2009) Population of small hive beetles (Aethina tumida Murray) in two apiaries having different soil textures in Mississippi. Sci Bee Cult 1:4-8

García-Fernández P, Santiago-Álvarez C, Quesada-Moraga E (2008) Pathogenicity and thermal biology of mitosporic fungi as potential microbial control agents of Varroa destructor (Acari: Mesostigmata), an ectoparasitic mite of honey bee, Apis mellifera (Hymenoptera: Apidae). Apidologie 39:662-673

Gerritsen LJM, Cornelissen B (2006) Biological control of Varroa destructor by fungi. In: Proceedings of the section Experimental and Applied entomology of the Netherlands Entomological Society, vol 17, pp 125-132

Haddad NJ, Fuchs S, Haddaden J, Kopelke JP (2005) Record of Sphecophaga vesparum Curtis, a natural enemy of Vespa orientalis in northern Jordan. Zool Midd East 35:114-116

Hamiduzzaman MM, Sinia A, Guzman-Novoa E, Goodwin PH (2012) Entomopathogenic fungi as potential biocontrol agents of the ecto-parasitic mite, Varroa destructor, and their effect on the immune response of honey bees (Apis mellifera L.). J Invert Pathol 111:237-243

Hanley AV, Huang ZY, Pett WL (2003) Effects of dietary transgenic Bt corn pollen on larvae of Apis mellifera and Galleria mellonella. J Apic Res 42:77-81

Hassan AR, Neumann P (2008) A survey for the small hive beetle in Egypt. J Apic Res 47:186-187

Havron A, Margalith Y (1995) Parasitization of Vespa orientalis nests by Sphecophaga vesparum Curtis in southern Israel (Hymenoptera: Vespidae, Ichneumonidae). Phytoparasitica 23:19-25

lancu R, Oprean L, Codoi V (2012) Organic beekeeping and bee products. Sci Papers Ser A Agron 55:302-305

James RR, Hayes G, Leland JE (2006) Field trials on the microbial control of varroa with the fungus Metarhizium anisopliae. Am Bee J 146:968-972

Kanga LH, Jones WA, Gracia C (2006) Efficacy of strips coated with Metarhizium anisopliae for control of Varroa destructor (Acari: Varroidae) in honey bee colonies in Texas and Florida. Exp Appl Acarol 40:249

Kanga LHB, James RR, Boucias DG (2002) Hirsutella thompsonii and Metarhizium anisopliae as potential microbial control agents of Varroa destructor, a honey bee parasite. J Invert Pathol 81:175-184

Kanga LHB, Jones WA, James RR (2003) Field trials using the fungal pathogen, Metarhizium anisopliae (Deuteromycetes: Hyphomycetes) to control the ectoparasitic mite, Varroa destructor (Acari: Varroidae) in honey bee, Apis mellifera (Hymenoptera: Apidae) colonies. J Econ Entomol 96:1091-1099

Kwadha CA, Ong'amo GO, Ndegwa PN, Raina SK, Fombong AT (2017) The biology and control of the greater wax moth, Galleria mellonella. Insects 8:61

Le Conte Y, Navajas M (2008) Climate change: impact on honey bee populations and diseases. Rev Scient Techn 27:499-510

Lodesani M, Costa C, Serra G, Colombo R, Sabatini AG (2008) Acaricide residues in beeswax after conversion to organic beekeeping methods. Apidologie 39: 324-333

Maini S, Medrzycki P, Porrini C (2010) The puzzle of honey bee losses: a brief review. Bull Insectol 63:153-160

Martin SJ (2004) A simulation model of biological control of social wasps (Vespinae) using mermithid nematodes. New Zeal J Zool 31:241-248 
Meikle WG, Mercadier G, Girod V, Derouane F, Jones WA (2006) Evaluation of Beauveria bassiana (Balsamo) Vuillemin (Deuteromycota: Hyphomycetes) strains isolated from varroa mites in southern France. J Apic Res 45:219-220

Meikle WG, Mercadier G, Guermache F, Bon MC (2012) Pseudomonas contamination of a fungus-based biopesticide: implications for honey bee (Hymenoptera: Apidae) health and Varroa mite (Acari: Varroidae) control. Biol Control 60:312-320

Meikle WG, Mercadier G, Holst N, Nansen C, Girod V (2007) Duration and spread of an entomopathogenic fungus, Beauveria bassiana (Deuteromycota: Hyphomycetes), used to treat varroa mites (Acari: Varroidae) in honey bee (Hymenoptera: Apidae) hives. J Econ Entomol 100:1-10

Meikle WG, Mercadier G, Holst N, Nansen C, Girod V (2008) Impact of a treatment of Beauveria bassiana (Deuteromycota: Hyphomycetes) on honeybee (Apis mellifera) colony health and on Varroa destructor mites (Acari: Varroidae). Apidologie 39:247-259

Mohammed SEAR (2018) First report of Apis mellifera carnica Ruttner (Hymenoptera, Apidae) in Saudi Arabia parasitized by a phorid parasitoid (Diptera: Phoridae). J Apic Res 57:565-568

Monceau K, Bonnard O, Thiéry D (2014) Vespa velutina: a new invasive predator of honeybees in Europe. J Pest Sci 87:1-6

Morse RA, Calderone NW (2000) The value of honey bees as pollinators of US crops in 2000. Bee culture 128:1-15

Muerrle TM, Neumann P, Dames JF, Hepburn HR, Hill MP (2006) Susceptibility of adult Aethina tumida (Coleoptera: Nitidulidae) to entomopathogenic fungi. J Econ Entomol 99:1-6

Nagai T, Inoue R (2004) Preparation and the functional properties of water extract and alkaline extract of royal jelly. Food Chem 84:181-186

Neumann P, Carreck NL (2010) Honey bee colony losses. J Apic Res 49:1-6

Neumann P, Pettis JS, Schäfer MO (2016) Quo vadis Aethina tumida? Biology and control of small hive beetles. Apidologie 47:427-466

Palmeri V, Scirtò G, Malacrinò A, Laudani F, Campolo O (2015) A scientific note on a new pest for European honeybees: first report of small hive beetle Aethina tumida, (Coleoptera: Nitidulidae) in Italy. Apidologie 46:527-529

Peng CY, Zhou X, Kaya HK (2002) Virulence and site of infection of the fungus, Hirsutella thompsonii, to the honey bee ectoparasitic mite, Varroa destructor. J Invert Pathol 81:185-195

Pettis JS (2004) A scientific note on Varroa destructor resistance to coumaphos in the United States. Apidologie 35:91-92

Poidatz J, Plantey RL, Thiéry D (2018) Indigenous strains of Beauveria and Metarhizium as potential biological control agents against the invasive hornet Vespa velutina. J Invert Pathol 153:180-185

Poinar GO Jr, Himsworth PT (1967) Neoaplectana parasitism of larvae of the greater wax moth, Galleria mellonella. J Invert Pathol 9:241-246

Rangel J, Ward L (2018) Evaluation of the predatory mite Stratiolaelaps scimitus for the biological control of the honey bee ectoparasitic mite Varroa destructor. J Apic Res 57:425-432

Read S, Howlett BG, Donovan BJ, Nelson WR, van Toor RF (2014) Culturing chelifers (Pseudoscorpions) that consume Varroa mites. J Appl Entomol 138: 260-266

Ricchiuti L, Miranda M, Venti R, Bosi F, Marino L, Mutinelli F (2016) Infestation of Apis mellifera colonies by Megaselia scalaris (Loew, 1866) in Abruzzo and Molise regions, Central-Southern Italy. J Apic Res 55:187-192

Richards CS, Hill MP, Dames JF (2005) The susceptibility of small hive beetle (Aethina tumida Murray) pupae to Aspergillus niger (van Tieghem) and A. flavus (link: Grey). Am Bee J 145:748-751

Rodríguez M, Gerding M, France A (2009) Selection of entomopathogenic fungi to control Varroa destructor (Acari: Varroidae). Chil J Agri Res 69:534-540

Rose EA, Harris RA, Glare TR (1999) Possible pathogens of social wasps (Hymenoptera: Vespidae) and their potential as biological control agents. New Zeal J Zool 26:179-190

Schiffer T (2017) Handlungsanleitung für artgerechte Bienenhaltung mit Bücherskorpionen. https://beenature-project.com/epages/6aa71639-792d4a95-9e8c-00453bab9a49.sf/de_DE/?ObjectPath=/Shops/6aa71639-792d4a95-9e8c-00453bab9a49/Products/01

Serebrov W, Gerber ON, Malyarchuk AA, Martemyanov W, Alekseev AA, Glupov W (2006) Effect of entomopathogenic fungi on detoxification enzyme activity in greater wax moth Galleria mellonella L.(Lepidoptera, Pyralidae) and role of detoxification enzymes in development of insect resistance to entomopathogenic fungi. Biol Bull 33:581

Sewify GH, Ibrahim YY, Salah El-Deen M (2015) Beauveria bassiana (Balsamo), a potential mycopesticide for efficient control of the honey bee ectoparasitic mite, Varroa destructor Anderson and Trueman. Egypt J Biol Pest Control 25: 333-337

Shapiro-llan DI, Morales-Ramos JA, Rojas MG, Tedders WL (2010) Effects of a novel entomopathogenic nematode-infected host formulation on cadaver integrity, nematode yield, and suppression of Diaprepes abbreviatus and Aethina tumida. J Invert pathol 103:103-108

Shaw KE, Davidson G, Clark SJ, Ball BV, Pell JK, Chandler D, Sunderland KD (2002) Laboratory bioassays to assess the pathogenicity of mitosporic fungi to Varroa destructor (Acari: Mesostigmata), an ectoparasitic mite of the honeybee, Apis mellifera. Biol Control 24:266-276

Steenberg T, Kryger P, Holst N (2010) A scientific note on the fungus Beauveria bassiana infecting Varroa destructor in worker brood cells in honey bee hives. Apidologie 41:127-128

Strauss U, Human H, Crewe RM, Pirk CWW (2010) The first report of storage mites, Caloglyphus hughesi (acaridae) on laboratory-reared Aethina tumida Murray (Coleoptera: Nitidulidae) in South Africa. Afr Entomol 18:379-382

Subbiah MS, Mahadeven V, Janakiraman R (1957) A note on the occurrence of an arachnid-Ellingsenius indicus Chamberlin-infesting bee hives in South India. Indian J Vet Sci Ani Husb 27:155-156

Torto B, Fombong AT, Arbogast RT, Teal PE (2010) Monitoring Aethina tumida (Coleoptera: Nitidulidae) with baited bottom board traps: occurrence and seasonal abundance in honey bee colonies in Kenya. Environ Entomol 39: $1731-1736$

Turchi L, Derijard B (2018) Options for the biological and physical control of Vespa velutina nigrithorax (Hym.: Vespidae) in Europe: a review. J Appl Entomol 142:553-562

van Toor RF, Thompson SE, Gibson DM, Smith GR (2015) Ingestion of Varroa destructor by pseudoscorpions in honey bee hives confirmed by PCR analysis. J Apic Res 54:555-562

vanEngelsdorp D, Evans JD, Saegerman C, Mullin C, Haubruge E, Nguyen BK, Frazier M, Frazier J, Cox-Foster D, Chen Y, Underwood R, Tarpy DR, Pettis JS (2009) Colony collapse disorder: a descriptive study. PLoS One 4:e6481

Villemant C, Zuccon D, Rome Q, Muller F, Poinar GO Jr, Justine JL (2015) Can parasites halt the invader? Mermithid nematodes parasitizing the yellowlegged Asian hornet in France. PeerJ 3:e947

Waller JB (1965) The effect of the venom of Bracon hebetor on the respiration of the wax moth Galleria mellonella. J Insect Physiol 11:1595-1599

Wanl M, Iwabuchi K, Mitsuhashi J (1994) Developmental responses of Galleria mellonella (Lepidoptera, Pyralidae) larvae to parasitism by a braconid parasitoid, Apanteles galleriae (Hymenoptera, Braconidae). Appl Entomol Zool 29:193-201

Wright N, Steinkraus D (2013) A scientific note on a protozoan pathogen of the small hive beetle. Apidologie 44:173-175

\section{Submit your manuscript to a SpringerOpen ${ }^{\circ}$ journal and benefit from:}

- Convenient online submission

Rigorous peer review

- Open access: articles freely available online

- High visibility within the field

- Retaining the copyright to your article

Submit your next manuscript at $\boldsymbol{\nabla}$ springeropen.com 